This is a self-archived - parallel published version of this article in the publication archive of the University of Vaasa. It might differ from the original.

\title{
Methodologies and methods of transnational learning
}

Author(s): Mariussen, Åge; Virkkala, Seija

Title: $\quad$ Methodologies and methods of transnational learning

Year: $\quad 2013$

Version: Final draft (post print, aam, accepted manuscript)

Copyright (C)2013 Routledge. This is an Accepted Manuscript of a book chapter published by Routledge in Mariussen, Å. (Ed.), Virkkala, S. (Ed.). (2013). Learning Transnational Learning. London: Routledge, on 29 April 2013, available online: https://doi.org/10.4324/9780203427156.

Please cite the original version:

Mariussen, A, \& Virkkala, S., (2013). Methodologies and methods of transnational learning. In: Å. Mariussen, \& S. Virkkala (Eds.), Learning Transnational Learning (pp. 155-195). London: Routledge. https:// doi.org/10.4324/9780203427156 


\title{
Chapter 5 METHODOLOGIES AND METHODS OF TRANSNATIONAL LEARN- ING
}

Åge Mariussen and Seija Virkkala

Book chapter 5 in Learning Transnational Learning. Edited by Åge Mariussen and Seija Virkkala (2013) Routledge Studies in Human Geography, pp. 155-195. Routledge: Abingdon.

\begin{abstract}
The chapter summarizes the discussions from sociology (Chapter 1), geography (Chapter 2), organizational theory (Chapter 3) and theories of transnational learning (Chapter 4) in a discussion of methods and methodologies of transnational learning. This is done in three steps (i) a discussion of methodological preliminaries, which are seen as spatial, organizational and cognitive, (ii) an extended discussion of the typology of globalization and transnational learning introduced in Chapter 1 and (iii) methods of transnational learning, which draws upon Chapter 4. In the method section, the following steps are identified, with reference to SECI process: (i) abduction (ii) translation (iii) evaluation and (iv) internalization.
\end{abstract}

\section{INTRODUCTION}

Most of the time, cognitive learning (see Chapter 1 in this volume) is likely to be enabled and restricted by spatial (see Chapter 2 in this volume) and organizational (see Chapter 3 in this volume) frameworks, and lock-in mechanisms, which create trajectories. Attempts at transnational learning are often motivated by visions that break with some of these spatial and organizational limitations, sometimes with reference to emergent (Chapter 1) institutional phenomena or megatrends driven by globalization. The examples used in this book are liberalization (NPM), multilevel governance in Europe (OMC, Smart Specialization), global communities defending the common interests of humanity (World Heritage), and Nordic values (see Chapters 1, 6, 8 and 13 in this volume). The special case of Nordic learning is discussed more comprehensively in Chapter 8.

This chapter shows how some of these forms of transnational learning may be analyzed within the parameters defined by SECI (see Chapter 3, this volume). The argument is that new knowledge creation facilitated through the analytical and organizational tools of SECI 
has a potential to change trajectories usually locked in by spatial and organizational restrictions. Accordingly, in the discussion on methods (see below), the chapter refers to approaches and tools that are based on SECI, which may be useful in organizing, monitoring and evaluating processes of transnational learning. In doing so, we draw upon some of the concepts introduced by Mariussen and Virkkala in Chapter 4 of this volume, such as translation and abduction. Finally, in the discussion on the practical application of the outcomes of transnational learning and innovation, the topic of emergence, introduced in Chapter 1, is reopened, from the point of departure of theories of institutional change. It is argued that continued work in this direction enables the development of analytical and methodological tools which may be used to explore empirically how transnational learning can change trajectories (see below).

\section{METHODOLOGICAL PRELIMINARIES}

In literature on policy transfer a distinction has been made between voluntary policy transfers, coercive transfers, and mixtures between these two extremes, such as policy transfer as conditionality for support (Dolowitz and Marsh 2000). For example, transnational learning may be forced upon a country through armies of occupation. But alas, Bonaparte is dead. The Red Army or the US Army may have clear visions regarding 'regime change' or similar objectives, but as we have seen lately, without local support combined with huge investments from the occupying force, boots on the ground are not likely to make lasting impacts. In countries with broken economies, reforms may be required by external helpers, such as the IMF, as conditions for support. In these cases, the external helper may have a clear vision and give authoritative advice, a model which is to be transferred. But the efficiency of these efforts depends upon cooperation with internal actor networks, something which should not be taken for granted.

As Latour (2005) points out, the earth is flat. Most of the time, transnational learning is voluntary and horizontal. This does not mean, however, that there is no such thing as powerful institutions. A crucial question is, as Latour poses it 'Where are the structural effects actually being produced?' (2005 page 175). In the absence of top-down coercion, what we have as a point of departure is various forms of cooperation, which, seen from a local or regional perspective, have to build on some kind of motivation. As we will see below, these sources of motivation are important 'drivers' in processes of transnational learning, and they are also important in understanding the dynamics of the cognitive, organizational and spatial processes involved in them. Policy transfer literature from the 1990s focused to a large degree on what Mariussen in chapter 1 of this book refers to as 'hard globalization', or Americani-

zation, based on the normative hegemony of the US/UK neo-liberal economies. The world 
was 'flat', but in this flat world, the USA was the hegemonic provider of best practice. In other words models had a standardized form. Core actors in this period were the OECD, national governments, as well as accountancy corporations diversifying from management consulting to government consulting, such as Price Waterhouse Coopers, KPMG and Arthur Anderson (Stone 2004). The outcomes of these forms of policy transfers varied between copying, emulation, mixtures of the two, and/ or inspiration (Dolowitz and March 2000). However, the original aim of policy transfers sometimes failed because they were uninformed, incomplete or inappropriate (Dolowitz and March 2000). The case presented by Hyyryläinen in chapter 6 of this book is new public management (NPM). NPM style policy transfers may be contrasted both with more contemporary processes of learning within the multi-level governance system in Europe, such as 'learning through difference' in the Open Method of Coordination (OMC), as well as with Smart Specialization (S3). Other important forms of transnational learning are driven by transnational communities supported by global institutions, which are motivated by a common interest in humanity. An extraordinarily successful case is World Heritage (WH), based on the voluntary participation of national governments that identify sites which should be protected, because they are a part, not just of the local or national heritage, but of the common 'world heritage' of humanity. In this chapter we will briefly mention experiences regarding learning municipal organization and regional innovation system development between Nordic countries. In these cases, learning is supported by Nordic institutions, promoting the rather heterodox phenomenon called Nordic values. Nordic learning is experimental, with no obvious points of coordination and no hegemonic countries as points of reference. The discussion on Nordic learning is continued by Mariussen in chapter 8 .

Assuming that there is a level of motivation, the question of how to carry out transnational learning arises. In approaching this question, we can draw from the discussions from Chapters 1, 2 and 3 of this volume. In sociology, geography and organizational theory there are somewhat different understandings of knowledge and learning. Whereas in organizational theory, knowledge is seen as assets and pieces of information, which may be objects of investment and administrative control, the sociologists referred to in Chapter 1 tend to see knowledge as shared and contextual beliefs. Shared knowledge can be dynamic, and it may accumulate strength, but it can also be fragile and, due to its contextual character, its existence and relevance as knowledge, it is only reproduced by social processes, which recreate 'sharing' and shared beliefs, or 'truths'. At the same time, shared knowledge is crucial to the ways in which societies work and reproduce themselves, or follow trajectories of development. Shared beliefs, assumed to be 'true', may be seen as the 'operation system' which determines or predicts how society evolves.

New knowledge is more easily absorbed if we can relate it to something we already know, as knowledge is the precondition for cumulative learning. In all types of societies, there are 
structural mechanisms protecting shared knowledge, and thus the continuity of the society. This is discussed more specifically in Chapter 1, where we describe the structuration theory (Giddens) and the selection mechanisms (SRA) of Jessop, which explain how the trajectory of national societal development is maintained through a process whereby only the external elements which fit together with the strategy already in place are selected. Similarly, actor networks or ANTs form 'black boxes' where the divisions of labour between different components of the network are taken for granted. The balance between knowledge protection and learning is fragile. If barriers protecting existing knowledge are removed, the truth may be destroyed, and cumulative learning may give way to uncertainty. This uncertainty is discussed in Chapter 1 with reference to Giddens' idea of globalization as 'Juggernaut', a monster creating chaos. Uncertainty following the opening-up of knowledge protection mechanisms is why the coordinated process of knowledge creation, explained by Nonaka through the SECI model, should start with the sharing of knowledge in a relaxed and friendly atmosphere. This friendly atmosphere is the socialization or originating ba, where actors are motivated to participate in the transformation of their knowledge and ways of working. This need for friendliness to promote openness and dialogue is drawn upon, as we will see below, in 'peer review', both in the somewhat heavy-handed way in which the OECD makes peer review based evaluations of countries and their economies, and in the way in which peer review is applied in the Open Method of Coordination and Smart Specialization in the EU.

Knowledge protection enables cumulative learning, but it may at the same time lead to a lock-in, and prevent learning. In societies where shared knowledge is based on religion or conservative ideologies, knowledge protection may be open and institutionalized. Existing knowledge may be defended with reference to holy and authorized texts, such as the Koran, the Bible, or the core books of Marxism-Leninism. These texts may have institutions explicitly set up as guardians of faith, to protect societies and their core knowledge against learning. Even democratic, modern societies may have constitutions that are based on 'eternal' principles, which cannot be broken without violating the constitution. But in most modern societies, where hegemonic belief is based on the ideas of European Enlightenment, there are also strong values indicating that knowledge protection can only be legitimized as a precondition for cumulative learning. This is because in modern societies, transparency, criticism and dialogue are generally accepted as the road to furthermodernization. In this situation, paradoxically, lock-ins are generally not accepted, yet, they exist everywhere. In other words lockins have gone underground in modern societies, they have become tacit.

With regards to regional development, tacit knowledge (which is transferred, for instance, through patterns of interaction, and which often prevents cooperation between universities and local industries) reproduces path dependency in regional economies and innovation systems. The existence of tacit knowledge leads to a routinized innovation system which is governed by lock-ins, turning it into a black box. These lock-in mechanisms are often unintended, 
as actors reproducing them may be unaware of their existence. Furthermore, they are usually not documented in written texts, and are therefore hidden from the outside view. The first empirical indication of a regional development lock-in is the path dependency (Harmaakorpi 2006) of the regional economy. A lock-in is empirically observable in a development trajectory where new or surprising outcomes do not take place, because the relations between actors in the regional innovation system are stable. Grabher defines regional innovation system lock-ins as functional, cognitive and political (Grabher 1993, quoted in Harmaakorpi (2006). This point is illustrated with reference to different levels of learning discussed by Virkkala and Mariussen in chapter 3 of this volume. A region with a stable specialization in one or a few sectors might be able to learn through loop 1 (continuing with already established strategies more efficiently). More innovative regions with sophisticated absorptive and developmental capacities and regional innovation systems are likely to be able to do a loop 2, that is, diversify into new industries, which are related to their path. However, particularly in successful and highly innovative cases, there is a danger of path dependency, and therefore a sophisticated regional knowledge base needs a high level of knowledge protection. Path dependencies can sometimes also be seen as the institutionalization of successful regional development partnerships and their innovation systems. The reason for this is, as pointed out above, that positive feedback mechanisms generated through successful cumulative learning experiences and innovation provide incentives which give the innovation system a stable structure. A successful innovation system may become a black box, locking the development path of the region into a trajectory. At that point, the organizational mechanisms of bounded rationality and lock-in discussed in Chapter 3 start to operate, and exploitation becomes more important than exploration.

The SECI process of knowledge conversion presented by Virkkala and Mariussen in Chapter 3 of this volume is an organized way of attempting to unlock black boxes by opening up tacit knowledge for analysis, peer review and other forms of external scrutiny and evaluation. This is also referred to as cognitive learning. Once tacit mechanisms are converted into a codified analysis, they become exposed and vulnerable to criticism, as new and better procedures may be discovered through their comparison with others. This is new knowledge creation, which might lead to a leap from learning in loop 1 to loop 2 or even 3, as discussed by Argyris and Schön (1978). As we have seen above, this movement away from protected tacit forms of knowledge (socialization) to codification (explication) where knowledge becomes 'plastic' and vulnerable creates uncertainty. However, in facilitating SECI as a coordinated process, this uncertainty is controlled; SECI encourages moving from tacit to explicit knowledge, and recombining the resulting knowledge with other forms of knowledge (learning), and implementing and socializing it within a new practice. Thus, SECI overcomes the dilemma that often forms between too much knowledge protection and too much learning, and it may be used to offset the mechanisms creating a lock-in in regional development. In developing the 
SECI theory and the idea of knowledge creating organizations, applied in knowledge management literature referred to in Chapter 3, Nonaka combined sociology with organizational theory.

Tacit mechanisms blocking learning is a well known phenomenon in geography and in different parts of the broader field of organizational theories. In the classic organizational theory, referred to in Chapter 3 of this volume by Virkkala and Mariussen, knowledge was at first seen as something that is embodied in humans. Furthermore, humans and their knowledge are seen to be potentially controlled by organizations. These organizational administrative mechanisms are seen as restrictive, as they define objectives with clear implications as to what is relevant and what is irrelevant to the operations of the organization. The top sections of the hierarchy decide what kind of knowledge is relevant and legitimate, and the vision of the leadership is biased towards the exploitation of solid existing knowledge rather than of uncertain new knowledge. Within this theory organizations possess bounded rationality, as they focus on efficiency rather than effectiveness, developing myopic visions.

An alternative to the idea of the restrictive and restricted organization in the organizational theory is learning organizations (see Chapter 3), such as adhocracies, which may thrive in dynamic and open innovation systems. The organizational theory sees knowledge as assets and information, which might not just be organizationally controlled, but also exchanged as objects in markets, networks, and other information sharing systems. By turning knowledge into markets some of the administrative boundaries restricting it are removed, and knowledge re-combinations may be achieved through projects linking different adhocracies within innovation systems.

Similarly in geography, as analysed by Virkkala in Chapter 2 of this volume, learning is seen as restricted by distance and enabled by proximity. Distances are covered by spatial patterns of flows of codified knowledge, combined with places, where interactive learning, including tacit knowledge processing and knowledge re-combinations, is possible. In geography, shared knowledge and innovation systems are seen as spatially embedded. Spatially embedded co-location, co-optation and co-evolution (Carayannis et al. 2008) may make radical changes of strategy difficult, leading to lock-ins. In looking at learning and knowledge on the regional level, one might say that regional development partnerships and innovation systems suffer from lock-in problems created both by the spatial patterns discussed by Virkkala in Chapter 2 of this volume as well as by the organizational mechanisms of bounded rationality discussed by Virkkala and Mariussen in Chapter 3 of this volume.

Cognitive learning is embedded in organizational and spatial networks which restrict learning and new knowledge creation, confining cognitive learning to specific trajectories, and thus creating paths and lock-ins. The restrictive mechanisms creating cognitive, political and 
functional lock-ins are mostly tacit. It is important, however, that the word 'restriction' should not be equalled with 'peripheral', as also modern and highly successful industrial clusters may develop lock-ins based on the tactics which created their success in the first place. Even if these clusters maintain a high level of innovation within their trajectory, due to their success they will not engage with exploring and detecting more radical shifts in their markets. One case in point is the success story of Nokia in Finland in the 1990s, where Nokia invested in research and development $(R \& D)$, and production facilities with high proximity to Finnish technological universities. These triple helix clusters, characterized, in this case, by close relations between Nokia, regional institutions and universit ies enabled a highly competitive strategy which was used for the better part of two decades. However, when the focus of the mobile phone industry shifted to Smart phones, driven by the I-Phone success, Nokia was not able to follow, because its main clusters were specialized in an outdated operative system (Symbian). The current attempt to turn Nokia around has resulted in the shift in the direction of the US model of organization described by Alice Lam as adhocracy (see Chapter 3 and below), combined with access to global innovation systems, in the case of Nokia through its alliance with Microsoft. The shift also meant that the cognitive learning process quite literally took a new direction, with a new operative system supported by a new set of networks of suppliers. This cognitive shift had deep implications with regards to the organizational structures and spatial patterns inside Nokia; the old innovation system was reflected upon, and a new direction was set. Going into learning loop 3 means to critically evaluate the ways in which the current innovation system and other practices work, and to be open to change when it comes to what kind of knowledge is seen as relevant. It is a way of breaking out of spatial, organizational and societal lock-ins. This discussion is summarized in the Figure 5.1 .

In the case of learning loop 1 or 2 , cognitive learning is restricted by spatial and organizational barriers. Breaking out of this restriction starts by opening up the process of cognitive learning for new external knowledge. This can be done through organizational facilitation. The knowledge conversion process of SECI enables a company to expose the tacit mechanisms restricting development, and invent new combinations. A distinction can be made between a lock-in (where only loop 1 and 2 learning is possible), breaking out, enabling loop 2 , and new knowledge creation, where learning may go into loop 3, and lead to the creation of new innovation systems. 


\begin{tabular}{|c|c|c|}
\hline Spatial & Learning loop 1-2 (lock in) & Learning loop 2-3 \\
\hline Organizational & $\begin{array}{c}\text { Regional dynamics and } \\
\text { change }\end{array}$ \\
$\begin{array}{c}\text { Restricting organizational } \\
\text { structures (bounded rational- } \\
\text { ities) }\end{array}$ & Enabling organizational struc- \\
Cognitive & tures \\
Lock in of cognitive learning & New knowledge creation \\
\hline
\end{tabular}

Figure 5.1. Restricting and enabling processes of learning loops.

The related societal, organizational and spatial structures, discussed in Chapters 1, 2 and 3, are outlined in table 5.1. As pointed out by Virkkala and Mariussen in Chapter 3 of this volume, knowledge conversion leading to new knowledge creation relies on a combination of cognitive and administrative (political and functional) steps in the SECI process.

For Nonaka, SECI starts with a knowledge vision. First, the corporate leadership (top) considers a proposal for a strategy of innovation coming from its middle management (middleup). The top then issues a generalized commitment, a vision, which opens up the process, gives normative approval, and legitimizes the allocation of resources (up-down). At the same time, this acceptance from the top opens up the organizational units involved (down), including the knowledge resources (both tacit and codified) of the corporation, for the horizontal process of knowledge sharing and socializing. In practice, this potential is realized through the setting up of a ba, supported by the middle management. Thus, importantly, the knowledge vision also creates the preconditions for emergence, as it sets the structure in 
motion. There is an external goal, a vision that functions outside the current routines, procedures, and tacit practices. This motion in a new direction, the vision or what Harmaakorpi, with reference to regional development strategies, refers to as 'the core process of futurizing', and imagination, can start a process which might open up the tacit knowledge of the black boxes. In other words, the SECI process, described by Mariussen and Virkkala in Chapters 1,2 and 3 in this volume, is set in motion. Emergence refers to an on-going process of development, in which an expectation, a feeling that something is missing, prevails. This empty point is where the external element, the result of transnational learning, should be directed at, as there it may fulfil a need. Emergence may be discovered by transnational communities of activism, who are arguing in favour of new and better solutions to local and global problems. In the case of Nokia, it was a speech, given by the new CEO, recruited from Microsoft.

Table 5.1. Cognitive learning, organizational and spatial structures, learning loops

\begin{tabular}{|c|c|c|c|c|c|}
\hline \multicolumn{2}{|l|}{ Dimensions } & $\begin{array}{l}\text { Learning } \\
\text { loop } 1 \\
\text { Socialization } \\
\text { protecting } \\
\text { lock in }\end{array}$ & $\begin{array}{l}\text { Learning } \\
\text { loop } 2 \\
\text { Knowledge ex- } \\
\text { ternalization }\end{array}$ & \multicolumn{2}{|l|}{$\begin{array}{l}\text { Learning } \\
\text { loop } 3 \\
\text { Recombination } \\
\text { New } \\
\text { knowledge } \\
\text { Path creation } \\
\end{array}$} \\
\hline $\begin{array}{l}\text { Society/ Cog- } \\
\text { nitive learning }\end{array}$ & & $\begin{array}{l}\text { Narrow se- } \\
\text { lection } \\
\text { mechanisms } \\
\text { Routines } \\
\text { Traditions }\end{array}$ & $\begin{array}{l}\text { Emergence } \\
\text { Dialogues } \\
\text { Peer reviews } \\
\text { Transnational } \\
\text { learning } \\
\text { through differ- } \\
\text { ence }\end{array}$ & $\begin{array}{l}\text { Abductions } \\
\text { Translations } \\
\text { Ant hills }\end{array}$ & \\
\hline $\begin{array}{l}\text { Organizational } \\
\text { and spatial } \\
\text { structures }\end{array}$ & tacit & $\begin{array}{l}\text { Bounded ra- } \\
\text { tionalities } \\
\text { Myopic be- } \\
\text { haviour } \\
\text { Garbage } \\
\text { cans } \\
\text { RIS lock ins } \\
\text { Low absorp- } \\
\text { tive capacity }\end{array}$ & $\begin{array}{l}\text { Learning or- } \\
\text { ganizations } \\
\text { Open systems } \\
\text { of innovation } \\
\text { Absorptive ca- } \\
\text { pacity genera- } \\
\text { tion }\end{array}$ & $\begin{array}{l}\text { Knowledge } \\
\text { creating or- } \\
\text { ganizations } \\
\text { Regional de- } \\
\text { velopment } \\
\text { platforms }\end{array}$ & plicit \\
\hline
\end{tabular}

Secondly, local actors are likely to evaluate a suggestion of improvement based on external experiences, from the point of departure of the logic of their on-going practices. Local practices might be highly successful, or for a variety of reasons, they may seem to be highly successful, without actually being it. Successful or perceived successful networks may, as we saw in Chapter 1, become black boxes. There should be some kind of regional development coalition or partnership which is able to ask and seek answers to difficult questions, open up black boxes, and make way for new priorities and strategies. Thirdly, as we saw in Chapter 4 with reference to the ant hill theory, in overcoming the resistance caused by black 
boxes, the external element has to be able to adapt to the new context in the receiving region in a different country through a translation of itself. In other words there must be support for the process of transnational learning itself which is able to overcome the dangers of fragmentation and isolation between the transnational project and the regional development strategy. As we saw in Chapter 1, with reference to Bob Jessop, there is also the issue of the strategy of the national elite, who are likely to assess the proposed external element from the point of departure of their own strategy, and select only what is seen as consistent with it for further use.

\section{GLOBALIZATION AND TRANSNATIONAL LEARNING}

We may now return to our discussion in Chapter 1, of forms of globalization and related strategies of transnational learning (see Table 5.2). In Chapter 1 we made a distinction between 'hard' globalization, multi-level governance, learning through global communities, and Nordic learning.

Table 5.2. Modes and strategies of transnational learning

\begin{tabular}{|c|c|c|c|c|}
\hline $\begin{array}{l}\text { Mode of Glob- } \\
\text { alization }\end{array}$ & Cases & $\begin{array}{l}\text { Main actors ena- } \\
\text { bling translation }\end{array}$ & $\begin{array}{l}\text { Vision - emer- } \\
\text { gence }\end{array}$ & $\begin{array}{l}\text { Theory of develop- } \\
\text { ment }\end{array}$ \\
\hline $\begin{array}{l}\text { Hard globali- } \\
\text { zation }\end{array}$ & $\begin{array}{l}\text { New public } \\
\text { management }\end{array}$ & $\begin{array}{l}\text { States, consultan- } \\
\text { cies, OECD com- } \\
\text { mittees, policy } \\
\text { makers }\end{array}$ & $\begin{array}{l}\text { Modernization, } \\
\text { increased public } \\
\text { sector productiv- } \\
\text { ity }\end{array}$ & $\begin{array}{l}\text { Principal Agent, } \\
\text { transaction cost the- } \\
\text { ory }\end{array}$ \\
\hline $\begin{array}{l}\text { Lisbon poli- } \\
\text { cies, multi- } \\
\text { level govern- } \\
\text { ance }\end{array}$ & $\begin{array}{l}\text { Open Method } \\
\text { of Coordina- } \\
\text { tion }\end{array}$ & $\begin{array}{l}\text { EU platform, na- } \\
\text { tional level net- } \\
\text { work contacts }\end{array}$ & $\begin{array}{l}\text { EU Lisbon poli- } \\
\text { cies, competition } \\
\text { with USA }\end{array}$ & $\begin{array}{l}\text { Experimentalist gov- } \\
\text { ernance } \\
\text { National systems of } \\
\text { innovation }\end{array}$ \\
\hline $\begin{array}{l}\text { Post Lisbon, } \\
\text { multilevel gov- } \\
\text { ernance }\end{array}$ & $\begin{array}{l}\text { Smart Spe- } \\
\text { cialization }\end{array}$ & $\begin{array}{l}\text { EU platform, re- } \\
\text { gional institutions } \\
\text { and partnerships }\end{array}$ & $\begin{array}{l}\text { The European } \\
\text { economic crisis/ } \\
\text { Agenda } 2020\end{array}$ & $\begin{array}{l}\text { Related varieties } \\
\text { Regional systems of } \\
\text { innovation }\end{array}$ \\
\hline $\begin{array}{l}\text { Global com- } \\
\text { munities and } \\
\text { institutions }\end{array}$ & $\begin{array}{l}\text { World Herit- } \\
\text { age }\end{array}$ & $\begin{array}{l}\text { Global institution, } \\
\text { states, regions }\end{array}$ & $\begin{array}{l}\text { Protection of cul- } \\
\text { tural and national } \\
\text { heritages, re- } \\
\text { gional develop- } \\
\text { ment as a side } \\
\text { effect }\end{array}$ & $\begin{array}{l}\text { History, archeology, } \\
\text { natural science }\end{array}$ \\
\hline $\begin{array}{l}\text { Nordic learn- } \\
\text { ing }\end{array}$ & $\begin{array}{l}\text { Municipal or- } \\
\text { ganization } \\
\text { Regional de- } \\
\text { velopment }\end{array}$ & $\begin{array}{l}\text { Bottoms up, re- } \\
\text { gional and na- } \\
\text { tional level, Nordic } \\
\text { institutions }\end{array}$ & $\begin{array}{l}\text { 'The Swedish } \\
\text { model', Danish } \\
\text { flexicurity, Finn- } \\
\text { ish innovation } \\
\text { systems }\end{array}$ & $\begin{array}{l}\text { Welfare state theory, } \\
\text { innovation system } \\
\text { theory }\end{array}$ \\
\hline
\end{tabular}




\section{New Public Management}

In the case of 'hard globalization' discussed in Chapter 1, diffusion is driven by normative influences coming from a global hegemonic power, which is regarded as superior, and which accordingly provides the model for 'modernization' and 'best practices'. Americanization was facilitated by powerful transnational institutions, such as the OECD, working together with transnational consultancies, often integrated in US accountancy corporations. The business idea of these consultancies was to produce best practice models, which could be standardized and transferred. The shared vision of modernization through the adaptation of US forms of organization opened up possibilities for horizontal cooperation inside the transnational community which believed in the master story. The hegemonic model was implemented by the OECD, which set up 'platforms', transnational institutions and committees, often combined with national peer reviews.

National peer reviews were understood as evaluations of nations, undertaken by committees of international experts, and combined with sequences of horizontal discussions on analysis and recommendations. One of the first was a peer review in Japan, undertaken in the early 1960s. Initially, as pointed out by Bob Jessop, learning through OECD relied to a large extent upon a normative neo-liberal approach, which was backed up by neo-liberal transnational networks, think-tanks and institutions, combined with communities of politicians, policy makers, experts, and administrators.

Learning from others may also be chosen by national and regional policymakers, following the wake-up call of an externally imposed economic shock, which demonstrates that the economy is not working the way it should. The economic turbulence in the USA and Europe in the 1980s initiated a new wave of policy diffusion and transfers, in a quest to solve economic problems. In Nordic countries, the liberalization of financial industries led to a bank crisis, and in order to tackle the problems that followed, the productivity of the public sector came under scrutiny. The solutions were policy reforms, aimed at increased productivity and competitiveness. In Eastern Europe, the transition following the downfall of the Iron Curtain led to a similar demand for neo-liberal public sector reforms. The flow of neo-liberal ideas and models was not just based on ideology, such as Reaganomics and Thatcherism, but also a broader intellectual movement inclined towards neo-liberalism.

In Nordic countries, the productivity of the powerful public sectors providing welfare state services was put on the table during the 1987-1990 crisis. Reforms in the direction of NPM and other neo-liberal solutions were embraced by unions and politicians defending the welfare state, as a strategy to prove that Nordic economies could become globally competitive and at the same time maintain a welfare state system with a high level of sophisticated public 
services, including a social safety net, available for all citizens. The unions and social democratic parties defending these ideas also supported the privatization of state owned industries (Mariussen et al. 1996), and other reforms in the labor market, where employment security was removed in return for labor market policies and instruments which gave the unemployed easy access to education, skill upgrading, and new jobs, as in the Danish model of flexicurity (Kristensen 2009).

This configuration of factors; the neo-liberal policy networks, transnational institutions, the hegemonic position of neo-liberal national business systems, and the symbolic capital of NPM as the best practice solution, opened up the strategic selection mechanisms of national elites in favor of NPM. An analysis of the diffusion and influence of 'New Public Management' (NPM) on public sector reforms setting up agencies is presented by Hyyryläinen (see Chapter 6 in this volume).

The result in the case of NPM was a rapid diffusion of new, related organizational forms initiated through transnational communities. Scientifically, the NPM reforms were based on the Public Choice and Principal Agent Theories as well as the transaction cost theory. However, it was not diffused only as a scientific paradigm, but instead through transnational networks of policymakers. According to Hyyryläinen, practitioner-basedness was an essential precondition in order for NPM to have a global impact. It made transnational learning possible in a completely different way to any other research-driven development until then (Chapter 6 , this volume).

The focus on diffusion through communities of policy makers was coordinated by the OECD through a string of transnational committees (starting with TECO in the 1980s, later PUMA in the 1990, and more recently SIGMA and GOV), which provided information and guidance to practitioners on how to draft legislations for the organization and functioning of the state administration. This type of coordination also included seminars and conferences which created micro-level 'peer pressure', including the production and sharing of information and analysis, 'naming and shaming' of winners and losers, and the collective development of joint transnational standards based on OECD indicators, carried out by policymakers in various countries. When it comes to the content of these reforms, Hyyryläinen describes the 'rise and fall' of a specific form of NPM policy; agencies. In practice, depending on the national preconditions, 'agencification' took place in several different ways, and under several different names.

One of the areas where 'agencification' succeeded was regional development agencies or RDAs (Bellini, Danson and Halkier 2012). In the middle of the 1990s, the 'model RDA' was described in the following way: 
1. They were based in the region, at a 'hands off' distance from government offices, and closely linked to regional partners

2. They supported regional firms through 'soft' policies, such as networking and clustering

3. They could address complex problems through the integration of several policy areas

However, the swift diffusion of the agency model led to problems, opening up possibilities for backlashes and 'agency bonfires', as agencies were replaced with other solutions. But in some situations agencies were also able to reinvent themselves. Smart Specialization approach is multi-scalar and multi-actor, and as such poses a challenge to the agency model(Dahlström et al. 2012). The RDA model can deliver fast and explicit results, and, according to Dahlström et al. (Figure 5.2) this reliance on explicit indicators and fast results may constitute a form of path dependency and make it hard for regional development agencies to relate to the requirements of quadruple helix knowledge dynamics in Smart Specialization. Other criticism against agencies has been that codifying functions and defining indicators have destroyed some important qualities of the previous forms of administration, organized as a 'Weberian' public sector. The recent 'big society' reform in the UK is another example of a situation that concluded in 'agency bonfires'.

Seen in retrospect one might ask whether the reaction against agencies was caused by a somewhat too rapid externalization in the first circle, when the functions of the public sector administration were codified and the indicators of performance set up. A frequent criticism of this kind of reorganization is that new models are approached too uncritically, creating 'fashions' of organizational solutions that come from abroad, in this case the UK, and as weaknesses are revealed, they are rejected too quickly. In positioning this kind of process in the SECI model it is possible to apply a long term perspective on the processes of transfer or transnational learning, which might open up possibilities for cumulative learning. 


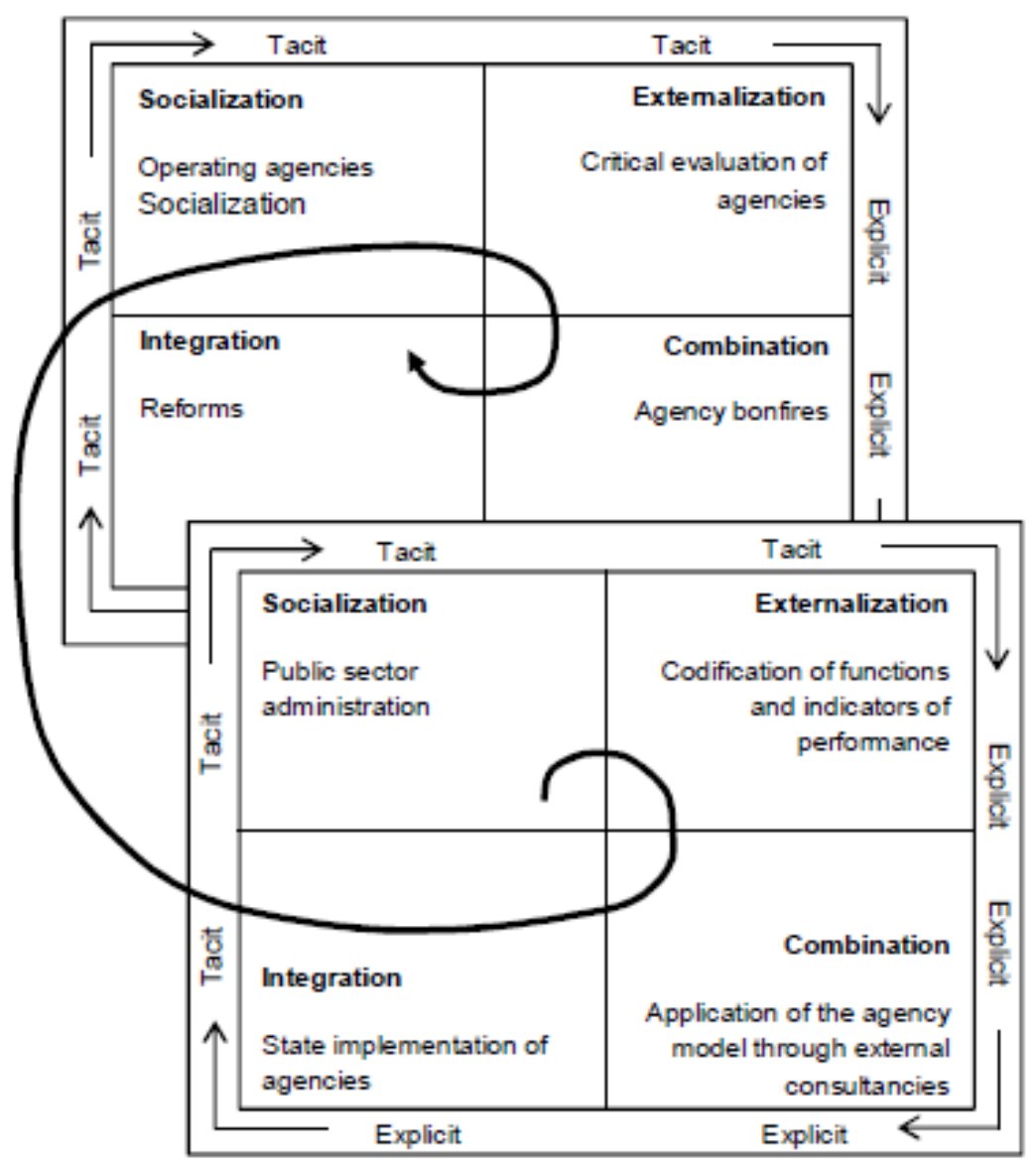

Figure 5.2. Agencies and agency bonfires as a SECI process..

\section{Open method of coordination}

The Open Method of Coordination was part of the Lisbon policies of 2000. Here, the EU tried to design a set of policies which could enhance transnational learning between member states. The motive was to compete with the leading economic power of the time, the USA. The Open Method of Coordination (OMC) was seen as an attempt to learn from the ways in which states in the USA learn from each other. The OMC aimed to be a 'means of spreading best practice and achieving greater convergence towards the main EU goals' (European Union 2004). In terms of theories of learning, it was based on learning through monitoring, also 
referred to as learning through difference, developed by Charles Sabel. Mainstream economic and innovation studies see learning as rational adaptation to global markets, and thus they overlook the limits of rationality identified in the organizational theory. Taking these limits into consideration, a pragmatist approach explains path breaking economic development through inter-firm learning by monitoring (Sabel 1992), benchmarking through indicators, and agreeing upon new routines. The OMC set down a framework for pragmatic deliberations in multi-level governance systems, where actors can look for and find new solutions, and thus change their routines (Sabel 2006).

More specifically, the steps of the OMC were:

1. Establishment of framework goals and metrics at an EU level

2. Elaboration of plans to reach the goals by national level units

3. Reporting, monitoring and peer review of results

4. Recursive revision of goals, metrics, and procedures in the light of experiences

The core element was the recursive approach to goals and operational methods, meaning that results were continuously reviewed, monitored and peer reviewed. This was, in other words, a sequence of bas (see chapter 3 ). The aim of peer review is to perform

a number of distinct governance functions, such as assessing the comparative effectiveness of different national and subnational implementation approaches, opening up opportunities for civil society actors to hold governments accountable at national and EU levels, identifying areas where new forms of national or transnational capacity building are required, and/or contributing to the redefinition of common policy objectives.

(Sabel and Zeitlin 2010: 3)

This begs the question of how the national selection system, described in chapter 1, and SRA would work. In the case of the OMC, a particular burden, as pointed out by Scharpf (1998; 2002), was the different and competing national models in Europe, specifically models that we in chapter 1 refer to as the US-UK neo-liberal model, and on the other hand the German model. Scharpf pointed out that areas which were seen as the core of each national model, and not open to national policy change, such as social policy, macro-economic employment policy, and labour relations, was likely to be kept outside of EU coordination. These sectors are crucial when it comes to the structure of national innovation systems. Sabel and Zeitlin (2010: 3) identify successful patterns of decision making in 13 policy sectors, from regulations of telecommunications to pensions. According to Sabel and Zeitlin

Although experimentalism conforms neither to traditional canons of input nor output legitimacy, the greater policy space it offers to nations and regions in pursuing 
broadly shared goals makes it arguably not only more effective but also more legitimate than competing forms of transnational governance. Yet the very polyarchy and diversity that make experimentalist governance attractive under such conditions can also make it difficult to get a transnational regime off the ground. Thus, too many participants with sharply different perspectives may make it hard to reach an initial agreement on common framework goals. Conversely, a single powerful player may be able to veto other proposed solutions even if he cannot impose his own. (Sabel and Zeitlin 2010)

The selection mechanisms allow the development of multilevel governance in some policy areas, while keeping others under national control. One of the areas where the OMC has had a more limited effect is national innovation policy. This illustrates the lock-in of national innovation systems, in other words that national governments tend to protect the core of their national models.

In an assessment of the impacts of experimentalist governance on EU cohesion policies, Mendez (2011) found that the coordinative discourses initiated by the Lisbon policies 'appear to have contributed to the creation of new organizational platforms', but at the same time that the harder procedural requirements and strategic reporting have been key contributing factors (Mendez 2011: 532). The debate on the actual effectiveness and outcomes of peer review as a mechanism of coordination is ongoing, and reflects different ideas of learning. In parts of the evaluation literature, for example, 'learning' is seen as the outcome of a formalized evaluation and monitoring procedure. The OMC version of learning and evaluation through peer review was to a large extent a tacit process, in which participants learned from each other in various ways, contributing to changes in national policies. This form of learning comes close to what we refer to as SECI, in which the OMC space would be considered ba. However, the causal chains leading from OMC deliberations (E - C in SECI) to policy implementation at the national level (I-C in SECI), were not coordinated, nor documented. In many cases, changes in national policy were not referred to as results of the OMC, but rather they were seen as changes emerging from within national systems.

An alternative perspective refers to the explicit coordination between cognitive learning and organizational implementation which was present in the OMC as EU regulations and standards. Some researchers argue that this 'hard' side of the OMC, its link to EU decision-making processes, and 'the shadow of hierarchy' implicit in 'naming and shaming', based on European level indicators, may have prevented the cognitive process of learning. This linkage with the multilevel EU system, which was at the core of the OMC, was not present in the classic OECD approach, where there was no explicit connection between the analysis in the OECD report and national policy implementation (Groenendijk 2009). Thus, it was possible for the OECD to go further in terms of cognitive learning processes. Similarly, Kröger (2009) 
argues that with the OMC horizontal learning was blocked in a number of ways. At the macro level, in dialogues between states, core concepts, such as 'social inclusion' were compromised due to widely different national approaches to social policy in the dominating countries. Furthermore 'Political guidelines and recommendations seem to stand in contrast with open-ended learning processes as do quantified targets which do not favor mutual trust relationships, but competition and bargaining.' (Kröger, opt.cit, page 7).

Also, Kröger correctly points out that lessons learned through peer reviews and other consultations and negotiations between experts are not necessarily implemented in practice. These and other arguments in the debate quite correctly identify several of the paradoxes which always follow any attempt to coordinate a cognitive process of learning leading to organizational implementation.

Seen in relation to the SECI process, the intention with the OMC is illustrated in Figure 5.3. 


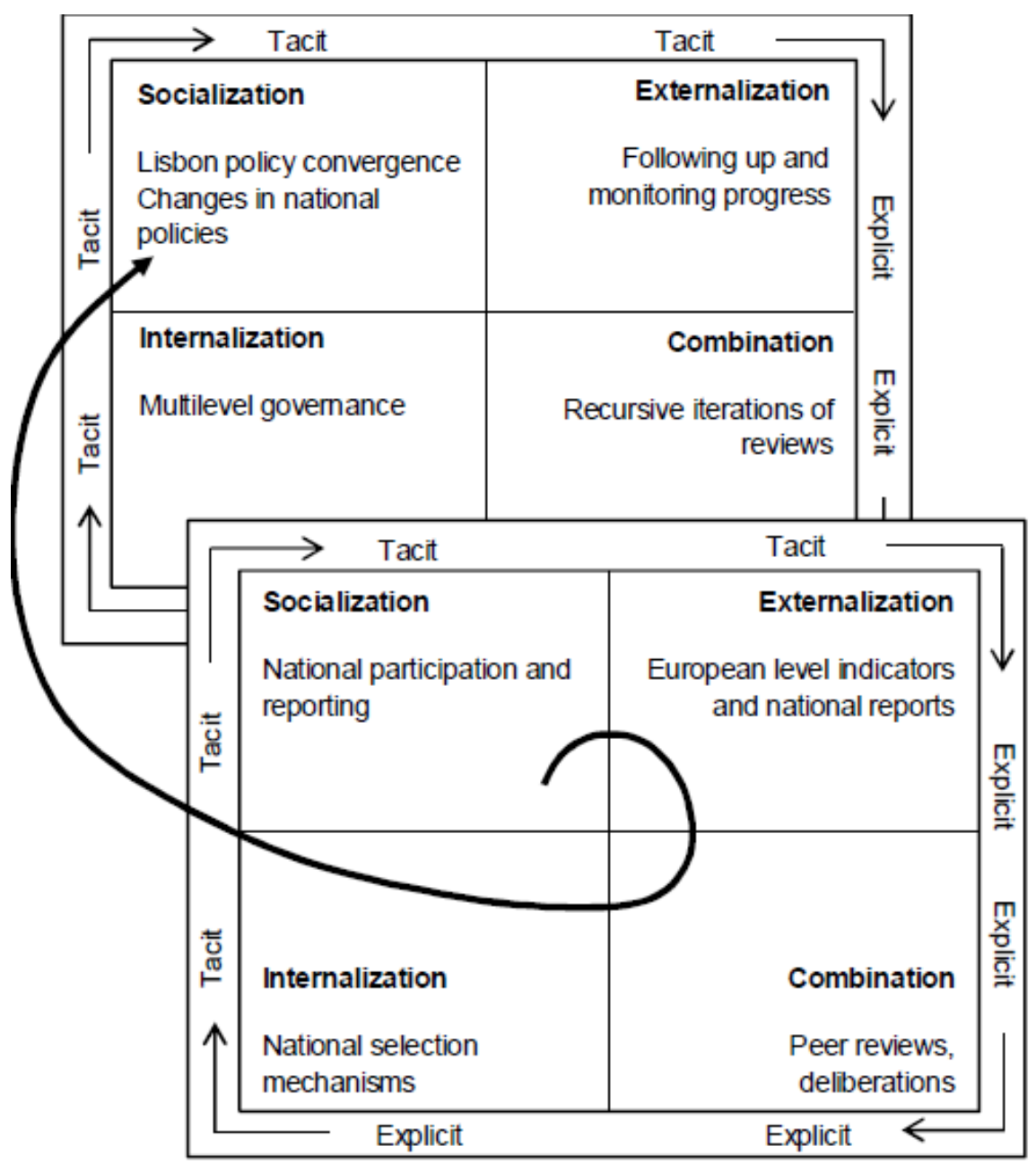

Figure 5.3. Open Method of Coordination as a SECI process.

\section{Smart specialization}

The OMC experiences with peer review were continued in the Smart Specialization initiative, which was introduced as part of the Horizon 2020 policies. In Smart Specialization the issue is not coordination between national policies, but rather the challenge of breaking up regional innovation system lock-ins, and creating a new strategy for European growth. Thus, the Smart Specialization approach bypasses 'the shadow of hierarchy' problem which is present in the OMC.

The global economic crisis which was initiated in the American housing market in 2008 has also hit the European economy hard. Moving outwards from the core financial industries it continued into the 'old' periphery in the Europe of 12; Greece, Ireland, Spain and Portugal, 
with Italy as an additional member. In these countries, the private and public sector debt, accumulated through the demand-driven growth leading up to the 2008 crisis led to severe problems for the states and financial industries. Debt problems created both in the private sector, as in Spain, and in the public sector, as in the case of Greece, led to the possibility of a sovereign default of one, or possibly several, Eurozone countries. The result of such an outcome would have been a financial crisis in the core EZ countries, France and Germany, who are the creditors of many Southern European countries. It also opened up the possibility for a breakup of the monetary cooperation linked to the EURO, and a collapse of the currency.

This extraordinary situation led to a completely new form of EU policy coordination, aimed at saving the EURO through giving support to the peripheral countries. Aid, in the form of credit, came with strict budgetary conditions attached. The conditions for receiving aid were austerity measures implemented in the form of deep cuts in private and public spending. In turn, the mobilization of resources for this support led to problems in the core countries in Europe, such as Germany and France. During the summer of 2012, Europe went into recession, with rapidly rising unemployment in peripheral economies.

The austerity measures introduced in countries struggling under high debt problems makes it evident that the classical Keynesian demand driven policies cannot be applied to deliver growth. An obvious alternative is to generate growth through innovation and other measures, which would enhance the global market competitiveness of peripheral countries. The Europe 2020 strategy was launched in June 2010. It has three priorities: smart, sustainable and inclusive growth.

Accordingly, the issue of coordination between science policy, where the Framework Programs are prominent, EU regional policy, where the Structural Funds are crucial, and EU social policy, has been on the table of the Commission for a while. The way the issue of coordination is approached, however, is not self-evident. One option could be to go in the direction of a science policy approach to growth, with emphasis on excellence, and simply put the resources of the Structural Funds at the disposal of the Agenda 2020 program.

However, there are two major arguments against such a move.

First, it is clear that the abilities of institutions in large European metropolitan areas that are commonly funded by science policy, i.e. universities and research institutions, to contribute to economic development, should not be taken for granted. Universities, one might suspect, may in several cases score high on science policy indicators, without contributing to the economy of the regions where they are located, or for that matter to the European economy at large. In confronting these issues, the Regional System of Innovation approach (RIS) is an 
obvious point of departure. RIS encourages a focus on the contributions of research to regional economic development, and to the coordination between research institutions, regional policy institutions and industry (triple helix). If the EU wants money spent on science to contribute to economic development, the RIS is an important strategy to take into consideration.

Secondly, in a situation where European convergence seems to suffer large setbacks, and when it comes to social integration, focusing only on high tech growth clusters in Germany, France and other core European regions would not make sense. The EU simply cannot allow peripheral regions to continue to fall even further behind.

Accordingly, merging these sectors means emphasizing regional innovation systems or RIS within the cohesion policy instrument, the Structural Funds. All regions are invited on board the Smart Specialization platform, including the peripheral regions. The Smart Specialization Strategy (S3) was launched as a platform in 2011 and it is coordinated by the Institute of Prospective Technology Studies (IPTS), located in Seville, Spain.

A 'platform' in this context refers to a framework of cooperation between regions, facilitated, by the IPTS and the Commission, in order to develop strategies for regions which sign up as members. The procedure is simple enough; European regions may sign up to be members of the platform, and in doing so, they commit themselves to developing a Smart Specialization strategy. This strategy is a condition for receiving structural fund support. To assist the regions, IPTS and OECD have developed a 'RIS 3 Guide' (European Commission 2012), which outlines a set of general principles for how plans should be developed, and what a Smart Specialization Strategy is. This framework is made open and flexible, in order to enable the creation of programs which are based on local conditions. There is a balance between top down (hard decisions on priorities) and bottom up guidelines of mobilization which usually pull in the direction of diversification.

The steps are:

1. Analysis of the national/ regional context and potential for innovation

2. Setting up of a well-functioning and inclusive governance structure

3. Production of a shared vision of the future of the country/ region

4. Selection of a limited number of priorities

5. Establishment of suitable policy mixes

6. Integration of monitoring and evaluation policies 
The platform, importantly, is a general framework: 'Consistently, this guide is to be interpreted as the 'trunk' establishing the skeleton structure from which a number of 'branches' may develop and grow.' (European Commission: 5)

The framework for the regional strategy of innovation is related varieties, combined with an emphasis on entrepreneurial discovery and 'key enabling technologies'. This shared framework enables comparison between regional strategies. Based on OECD experiences, the platform organizes conferences where regions are invited to present their strategies, and be "peer reviewed' by policymakers and specialist planners working with the same type of plans.

The idea behind the platform is to help regions to transform themselves. The challenge for Smart Specialization is not that it is linked to new forms of EU regulations or changes in national policies, but rather that it is up against the lock-in mechanisms of regional innovation systems.

\section{The World Heritage}

The Convention Concerning the Protection of World Natural and Cultural Heritage was set up in 1972 in order to protect certain places with valuable natural or cultural heritages against destruction and neglect. The protection provided by the convention takes as a point of departure a scientifically based World Heritage List. The World Heritage Convention text states in clear terms why this institution was established. The natural and cultural heritage of the world was threatened ...'not only by the natural causes of decay, but also by changing social and economic conditions which aggravate the situation with even more formidable phenomena of damage and destruction.' (UNESCO 1972: 1).

It was the damage and destruction related to the Aswan Dam project which led to the formation of the Committee. The Convention points out that because protection at the national level is too weak there is a need for a new form of global governance. This new form of governance is supposed to be conducted on behalf of 'the international community', in this case represented by the UNESCO Intergovernmental Committee, in cooperation with national partners. The main task on a global level is to define, in a centralized manner, the World Heritage Sites, based on scientific criteria. These definitions and sites are then included in the World Heritage List of areas to be protected by national partners. In the 1972 convention, the local or regional community is not given an active role in the governance of the heritage. However, it is required that the national partners give the heritage a 'function in the life of the (local) community'. The national partners are also encouraged to integrate protective measures in local planning, and to set up one or more services for the protection, 
conservation and presentation of the heritage with an appropriate staff equipped with adequate resources.

However, as pointed out by Drost in 1996, paradoxically this List created a new threat, as it was used by tourists to identify destinations for their travels. The paradox of tourism and sustainability in relation to the World Heritage was formulated by Drost in the following way:

By generating revenue and drawing world attention to their importance, tourism can be a positive force for the preservation of World Heritage. However, the unprecedented growth of tourism creates a number of concerns over the environmental and cultural identity of these destination areas and has led to a re-examination of tourism development in the light of the increasingly popular concept of sustainable tourism. (Drost 1996: 479)

Thus, inclusion of a Site on the World Heritage List could speed up the process of destruction by increasing the inflow of tourists beyond a sustainable level. Accordingly, in 2001, the World Heritage Committee instituted a 'World Heritage Tourism Program', focusing on 'sustainable tourism'. In 2002, the program was followed up with a Practical Manual for World Heritage Site Managers (UNESCO World Heritage Centre 2002), which was based on a broad summary of experiences and insights from different World Heritage Sites.

The World Heritage has been a success. There is strong competition between regions and countries for their sites to be included on the World Heritage List. However, this has created tension inside the Committee between representatives from different countries, i.e. politicians who want their candidates to be included, and the experts responsible for the scientific evaluation and decision making. The obvious danger is that too many could be included, that the value of the brand name becomes inflated, and that the scientific criteria are weakened. The Committee giving access to the World Heritage List may exclude sites which are not managed properly. At the same time, beyond the threat of exclusion, the committee does not dispose of instruments for interfering in the ways in which the state takes care of its sites. In areas where states fail, like Afghanistan and North Africa, this has had negative impacts, as sites have been destroyed by Al Qaida. It is feared that in some cases, the inclusion of a site on the WH List may have made Al Qaida more aware of these sites, and of the support they enjoyed from Christian countries, leading to the organization targeting some of these sites. If we look at the ways in which World Heritage protection is practiced in regions that appear on the World Heritage List, such as the Kvarken World Heritage Site, it is obvious that both national and regional actors use sources of trans-national governance, such as EU programs (Leader, Interreg) and Nordic institutions, with other principles and methods of promoting regional development through tourism. This has also led to the emergence of networks of 
cooperation between researchers in different parts of the world, who are studying and comparing ways in which locals cope with the challenges of globalization (see chapter 11 in this book).

An interesting aspect of WH in the context of our discussion is that it performs a cognitive learning process where a natural area or an old building is reclassified as part of the common heritage of humanity. This process has a strong center, the WH Committee, and the national governments acts as its 'middle management', with the responsibility of having to propose a Site, and to implement the protective measures, once the Site has been designated. Research into the local processes following such a move indicates that there may be several different local interpretations of what the Site actually is (see Chapter 12 in this volume). However, with the exception of the black box of Al Qaida, locals are generally either supportive or at least accepting of the decisions made by the WH Committee. In many cases, this has lead to enhanced economic development on the regional level. This is a successful middle - up down process of transnational learning, an abduction where a Site is repositioned into a completely new context which is defined at the global level, but that has deep implications for the locals.

Therefore, one might add, this success rests to a large extent upon the symbolic capital of the World Heritage List in the global tourist market.

In the format of the SECI model, the cognitive process described above may be understood as two sequential Bas (see Figure 5.4). 


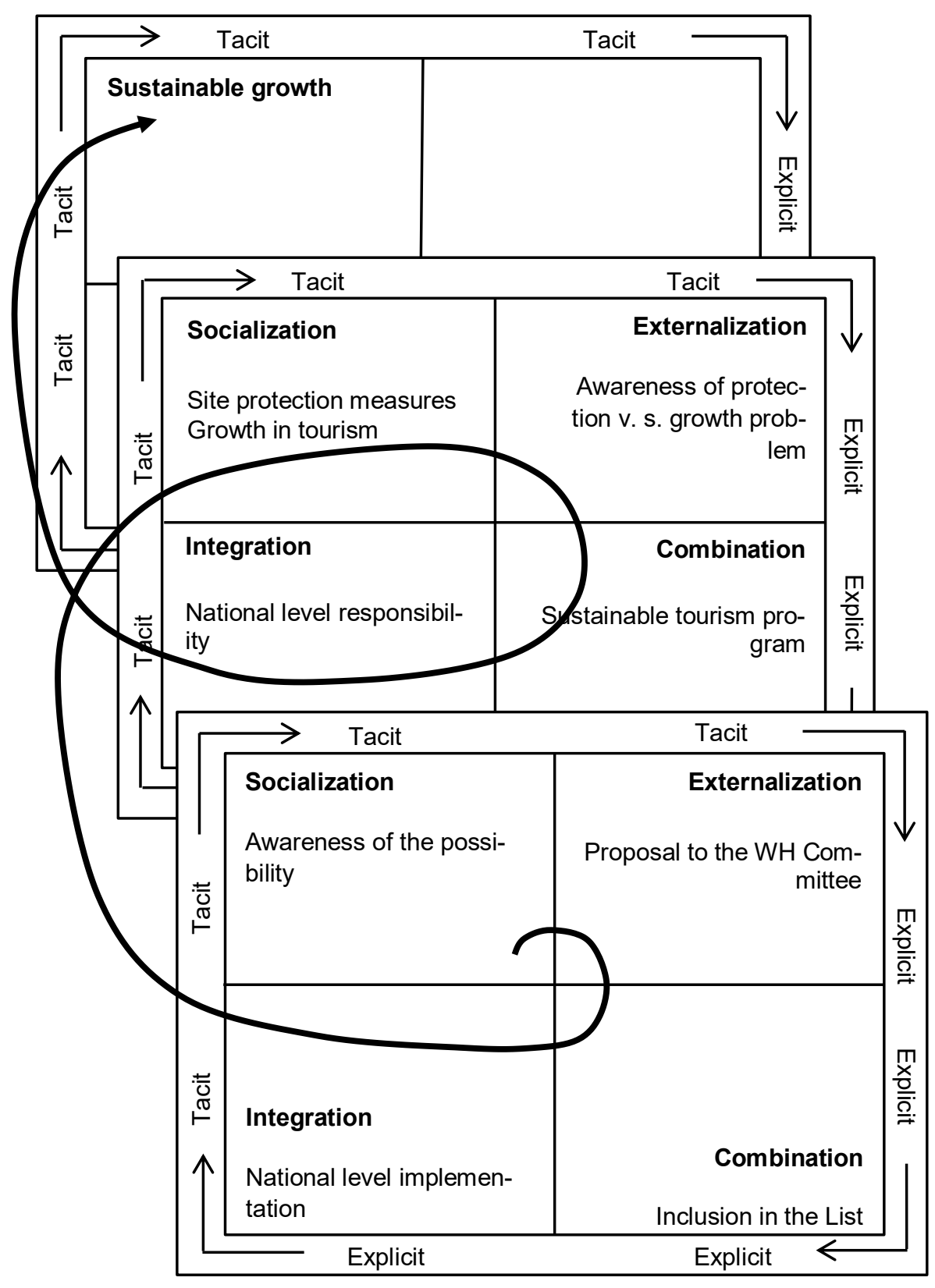

Figure 5.4. World heritage site process as a SECI model.

\section{Nordic cooperation}

In several cross border regions, transnational learning is institutionalized. However, an exchange of ideas may also take place in more loosely structured regional networks between different countries which recognize each other as struggling with similar challenges with 
regards to development. In Nordic cooperation, institutions facilitating transnational learning are well established, including communities of experts with 'stocks of shared knowledge', and close ties between transnational, national and regional policy networks. A case in point is networks and institutions focusing on municipal organization and spatial planning in Nordic countries, supported by Nordic institutions. The vision underlying several of these strategies is often based on values closely related to Nordic welfare societies, as well as shared identities based on a common history and culture.

\section{Successful transnational learning}

We may now answer Latour's question, mentioned in the introduction to this chapter, of where structural effects are actually produced.

Structural and institutional changes start with the creation of motivation, a vision which says that the present state of affairs is not sufficient. Motivation based on a shared vision unlocks the existing system, and creates the emergence (see Chapter 1 and above) which opens up the existing structure for new knowledge creation, in other words, cognitive learning. The idea of a shared vision flies in the face of existing institutional and organizational tensions, lock-ins, and conflicts. Accordingly a crucial issue in the initial stage is to shape an institutional and organizational framework capable of moving from the vision to initiating, supporting and protecting the cognitive learning process.

SECI starts with socialization, explication and combination.

In the case of World Heritage, the highly visible successful cases inspire followers. In several cases there is an explicit and easily observable causal connection between having a vision of becoming World Heritage, a successfully performed proposal process, inclusion in the World Heritage List, and a successful outcome in terms of national and local pride and economic input produced by tourism. The cognitive learning process related to the analysis of the Site which underpins the application and reviewing process carried out by the global Committee, is explicit, well regulated and crucial to the outcome, which is a conceptual redefinition of the Site, based on clear and codified criteria of evaluation. What has remained outside the regulations of the Convention is the local learning process, where challenges related to Site protection and tourism must be solved. Accordingly, the basic global - local institutional structure grows additional layers, as illustrated by Georg and Svels in Chapter 12 of this volume, within which supportive transnational communities of sociologists study how locals come to terms with this process, and how conflicts on the ground between tourism entrepreneurs and site protection are solved, through the promotion of 'sustainable tourism'. 
In the case of New Public Management, there was a powerful and hegemonic neo-liberal call for making the public sector more modern and efficient, which encouraged national policy makers to make swift and wide-ranging reforms. Core decision makers were highly motivated, and capable of supporting and implementing the reform process, assisted by the OECD and various other helpers. However, critics have questioned whether these reforms were really based on a thorough understanding of the qualities and operational knowledge of the old regime of bureaucratic public management. This relates to the initial move from socialization to externalization, where the knowledge of the old system of delivering public services is supposedly analyzed and brought into the process. Critics say that there is little cumulative learning involved in a process where first agencies are introduced, and once their initial flaws come to the surface, replaced with something else. On the other hand, it has also been pointed out that the existing agencies, in particular regional development agencies, have a considerable ability to correct mistakes and redefine themselves in order to meet new challenges.

In the case of the OMC, motivation has been more divided. The Lisbon agenda from 2000 aimed at, and succeeded in creating EU level policy convergence in several policy sectors in which the Commission did not actually have competence. On the other hand, within the EU there are several competing national models that protect themselves against too much convergence on core issues. A strong argument in favor of the OMC was that the process was designed to work its way through several iterations of peer reviewing and debates, and that this long term process leads to the creation of new national policies that produce institutional change, convergence towards the Lisbon objectives, and a new form of coordination and multilevel governance in Europe, which could not have been reached in other ways.

After the phase of externalization and combination, in other words new knowledge creation, comes the integration of knowledge into practice. When we apply the SECI perspective to the chain of events, we discover that the longer term impact of most of these processes is institutional change, which transform spatial structures. The WH Sites are included in a global institutional order which seeks to protect natural and cultural heritage, and at the same time to encourage economic development through increased tourism. The OMC as a process was an explicit step in the direction of a new institutional order in Europe, based on multilevel governance. NPM, on the other hand, enabled a new form of regional organization; regional development agencies.

Seen in relation to spatial and organizational lock-ins, and conflicting institutional arrangements, interests and values, the core issue in the cases referred to in Table 5.3 is how to enable a type of coordination which puts the cognitive process 'in the driving seat'. In successful cases of transnational learning, the cognitive processes of new knowledge creation are enabled through adequate organizational coordination and institutional protection. This takes place in the initial 'breakthrough', in the slower process of cumulative learning leading to 
institutionalization, where new practices become routines, and in maneuvers aimed at correcting the course of development by avoiding fallacies and maintaining a longer term cumulative learning process. The methodological framework, which makes it possible to analyze, coordinate and monitor these challenges and protect the cumulative learning process, is SECI, presented by Virkkala and Mariussen in Chapter 3 of this volume. Below we will discuss some of the tools of this method, and in the final section of this chapter, we will return to a more general discussion of the preconditions of cumulative learning, with reference to the different ways SECI may drive institutional and structural change.

Table 5.3. Spatial, organizational and cognitive dimensions of transnational learning processes.

\begin{tabular}{|c|c|c|c|}
\hline Dimensions & World Heritage & $O M C$ & NPM \\
\hline Spatial & $\begin{array}{l}\text { Global protection } \\
\text { and development } \\
\text { of the Sites }\end{array}$ & $\begin{array}{l}\text { European conver- } \\
\text { gence on Lisbon } \\
\text { objectives }\end{array}$ & $\begin{array}{l}\text { Global conver- } \\
\text { gence towards } \\
\text { neo-liberal forms } \\
\text { of organization }\end{array}$ \\
\hline Organizational & $\begin{array}{l}\text { Contract between } \\
\text { the WH Commit- } \\
\text { tee and the state }\end{array}$ & $\begin{array}{l}\text { Multilevel govern- } \\
\text { ance }\end{array}$ & Agencies \\
\hline Cognitive & $\begin{array}{l}\text { Global level defini- } \\
\text { tion of the Site, } \\
\text { based on a pro- } \\
\text { posal from the } \\
\text { state } \\
\text { National and local } \\
\text { learning regarding } \\
\text { site protection and } \\
\text { sustainable tour- } \\
\text { ism }\end{array}$ & $\begin{array}{l}\text { Common criteria, } \\
\text { indicators, conver- } \\
\text { gence on Lisbon } \\
\text { objectives } \\
\text { Peer reviews and } \\
\text { deliberations }\end{array}$ & $\begin{array}{l}\text { Redefining public } \\
\text { services from be- } \\
\text { ing the responsi- } \\
\text { bility of a hierar- } \\
\text { chical public sec- } \\
\text { tor to that of a } \\
\text { 'hands-off' agency }\end{array}$ \\
\hline
\end{tabular}

\section{METHODS}

In the context of the SECI model we can now define transnational learning through a process which combines the cognitive and organizational requirements of transnational learning through knowledge conversion. This happens through abduction (based on good practice analysis and comparative analysis), translation (combination), selection (internalization), and absorption (socialization), which are combined through the SECI process. Originating ba is the region receiving the new good practice, in which local actors begin to assess their existing 
norms of behavior, making an analysis of their regional practices, perhaps through peer reviews carried out by critical friends from other regions. Abduction in this context refers to the process by which actors in one region search for new elements and good practices from other regions (see Chapter 4 in this volume for broader discussion). It occurs in the interacting $\mathrm{ba}$, in the space where good practice created by the actors in the sender region is formed as an archetype, and which is then evaluated by regional actors in the receiving region. In the systematizing ba the archetype is translated through combining its generalized elements with information which is specific to the receiving region. In the exercising ba the archetype is evaluated, selected and justified, and the new explicit knowledge becomes internalized by actors in the receiving region. After that the new and improved regional practice is absorbed and socialized in the receiving region (Figure 5.5). The second round of the knowledge spiral starts with a new originating ba.

Since tacit knowledge held by individuals is the basis of organizational knowledge creation, it seems natural to start the process of transnational learning by focusing on tacit knowledge. Tacit knowledge cannot be communicated or passed onto others easily, since it is acquired primarily through experience and not easily expressed in words (Nonaka and Takeuchi 1995: 85). However, with the help of good practice analysis some of the tacit knowledge of experts can be made explicit. We will first present the method for analyzing good practices and then the tools for their comparison, both being essential parts of abduction. After that we will examine the process of the translation of good practices, and finally the internalization of the translated new knowledge. 


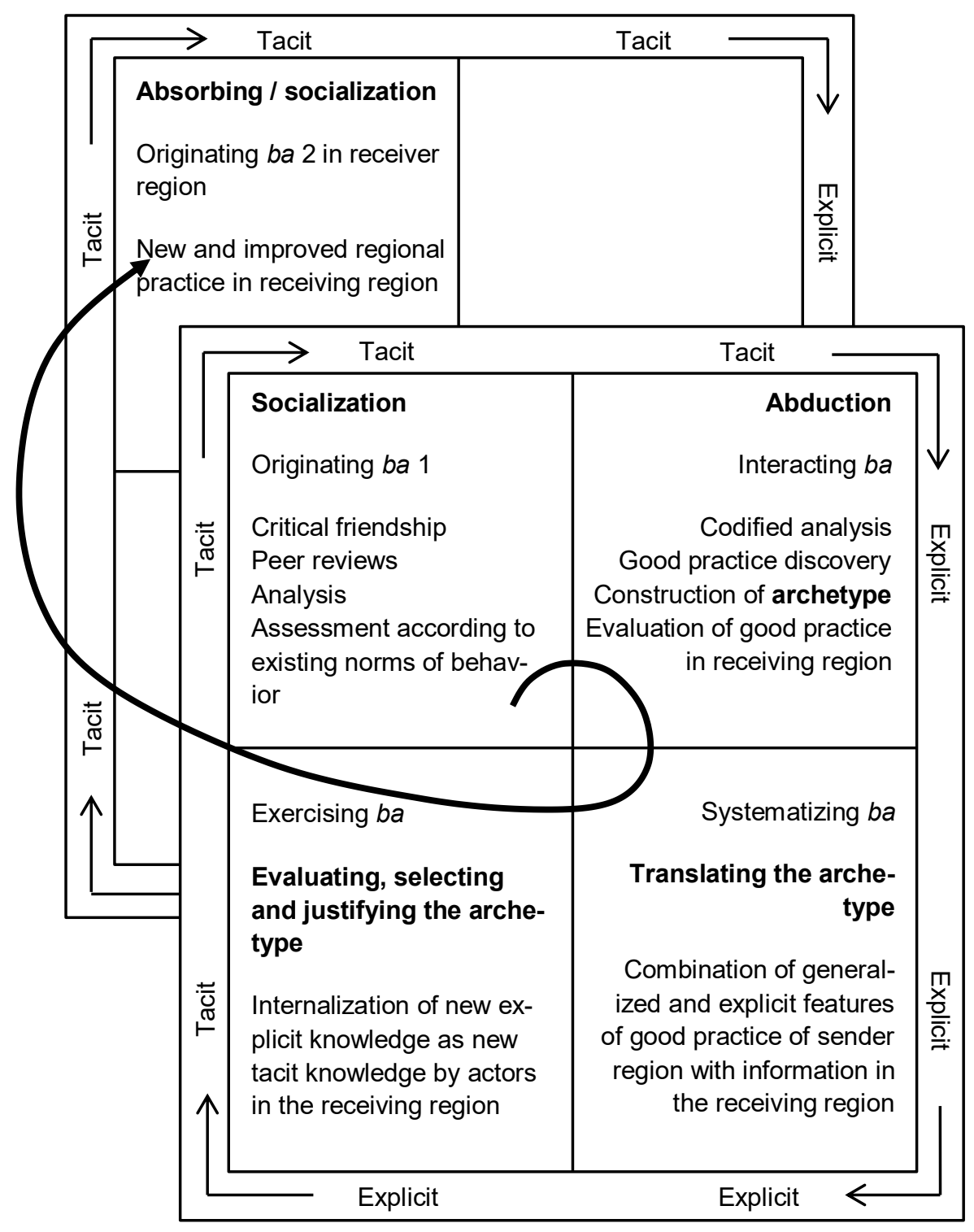

Figure 5.5. The cognitive and organizational requirements of transnational learning.

\section{Abduction: Good practice analysis and focus group meetings}

In political and management studies, there is a lot of literature on best practices. However, instead of the notion of best practice, we use the concept good practice in order to emphasize the context of the practice. What is good practice in one place cannot be described as such everywhere, though some of its elements might fit in another locality. Good practice analysis is a way of thinking, oriented towards constant learning, feedbacks and reflection on what 
works, what doesn't, and why (Vesely 2011). A good practice analysis can be constructed by researchers, through combining several sources of information. Interviews with key actors are the main source of the story or narrative of good practice. Finally researchers may present a complete success story, explaining what the regional actors have achieved and why.

However, some local actors may be highly conscious of their achievements, and in these instances, we should be more questioning of the story of good practice. Also, the informants may not necessarily have a complete overview of the unique institutional and structural context which explains why they are doing what they are doing in the first place. For instance, national institutions are easily taken for granted. One possible solution to this problem could be to 'deconstruct' these local success stories, and seek independent verification.

In order to test a hypothesis regarding the transferability of good practices, they must be reported in a way, which is understandable to another group of equally practically oriented people, in other words the focus group members, in the receiving country. Here, the new practices are confronted with another set of internalized operational knowledge, which is the knowledge enabling the corresponding, perhaps not such a good practice in the receiving region of the other country. We might expect a tension between these two practices, which is why transfer should take place in a specific field, in this case, the focus group meeting.

What we are referring to as a good practice story is a somewhat generalized or abstract analysis of what caused a certain good achievement in the first place. This corresponds with what Nonaka and Takeuchi refer to as an archetype. The archetype is a concept which should be created through a case study, and then justified, rejected, or modified in a focus group meeting (Nonaka and Takeuchi 1995: 85-7). In some cases, the archetype and the good practice may be identical, but an archetype can also be a modification, taking the abstract spirit of the good practice, and incorporating it into the specific institutional and geographical context of the receiving country.

The definitions of good practice emphasize functionality (what works and generates learning), processes (how to achieve the objectives of an activity), or innovativeness and transformability (new approaches, procedures and practices) (Vesely 2011). We define a good practice in regional or local development through the following dimensions:

1. A good practice within local or regional development policy is a separate entity (unit, process, sector, network etc.) which can be separated from its context.

2. A good practice is innovative, i.e. it brings something new to the locality and its development.

3. A good practice has content, which is neither too general nor too specific. An entrepreneurial spirit, for example, is too general for our purpose. On the other hand, the business conducted by an individual firm as such is too specific. Instead, 
the concept should be contextualized and related to the locality and local development policy.

4. A good practice is an entity which can be compared, at least to some degree, with other good practices.

5. A good practice has something from which actors in other regions can learn. It has some degree of transferability.

6. It is possible to repeat a good practice, or at least some elements of it.

7. A good practice has some kind of a measured or expected outcome which improves the wellbeing of the inhabitants or the sustainability of the locality, and increases the innovativeness of firms or the learning capability of the locality.

8. A good practice has a formal structure. It is organized and certain actors are involved in it.

A good practice can be defined as locally anchored, consisting of something extraordinary, an achievement which is expected to have a potential for telling others something, giving them new ideas which they might use in practice. Good practice can be, for example, local competence building strategies (Chapter 9, this volume) or regional networking strategies of actors in tourism (Chapter 11, this volume). Good practices can be looked for, identified, and analyzed in a report that is then presented at a focus group meeting. This 'good practice report' can include the following points:

- The contribution of a good practice to local/ regional development

- The context of the good practice: Which global, national, local factors enabled the achievement?

- The good practice story: What were the chains of events/actions/strategies/programs/policies/methods which resulted in the achievement?

- A hypothesis regarding transferability: We think this achievement is possible in the context of another country!

Constructing good practice stories as narratives can be based, for example, on the 'learning history methodology' (Mariussen 2010; Virkkala and Niemi 2006). In this methodology, the idea is to show not just what people have done, but also what they were thinking, what assumptions they had made, how they reached their decisions, what others thought about their actions, and how they expected to move forwards. The method includes reflective interviews with the core group of people behind an achievement, the distillation of the data, and writing an overview of the process behind the achievement (Massachusetts Institute for Technology 2012). 
The empirical data needed for the analysis of a good practice can be gathered through interviews and from secondary sources. The analysis includes a weak hypothesis (why the good practice?), the context of the good practice, the structure of institutions, practices and organizations enabling it, the process behind it, its impacts, and its transferable elements - what can others learn from the good practice?

Narrative is a means of analyzing, presenting and organizing qualitative data in order to make it intelligible. It is a spoken or written account of connected events, a story. Locating events within a meaningful story is one way of explaining them, and narratives are the principal means whereby humans make their experiences meaningful both to themselves and to others (Polkingthorne 1988). Narratives are used in explaining sequences of specific events over time, and in organizing events and actions in a coherent whole by showing the connections between them and the ways in which these linkages combine to produce end results or consequences. Specific events and actions in a sequence lead to a certain outcome, in the context of this article, for example, to good practice (Thomas 2004: 224-6). A key element of a narrative is its plot or organizing theme, which functions as the story line or organizing principle that gives meaning and significance to events by showing how they are related to each other. Plots are not themselves part of the data but are introduced by the analyst; their status is akin to that of theories. They organize the chains of evidence and reasoning in support of an explanation while also showing why alternative explanations are unsatisfactory. Stories can be fragmented, flowing, emerging and networking. Boje (2001) introduces some methods which can be used in non-linear story-telling, when stories are fragmented and polyphonic. Narrative explanation can never be final because new information may emerge that changes the understanding of events.

A particularly important aspect of narratives, based on the learning history methodology, is the identification of critical incidents. By 'critical incident' we mean an event which uncovers, illustrates or lays bare some key relationships in relation to a good practice and the actor network producing it. A critical incident normally consists of one of the activities of the actor network which had some transformative effect, in other words an event leading to change, where it might be possible to relate something within the nature of the actor network to the outcomes (effects) of their activities. A critical incident can be, for instance, a decision to start operating a certain good practice. It can also be a story of how a particular decision, made on a higher level, say, a national decision to finance a project, was taken in a way which decisively influenced, for instance, the micro level of a firm, or economic development on a regional level. Critical incident analysis allows us to substantiate the actor network 'histories' and make intersections between different levels of analysis. However, information on critical incidents should be cross checked using data from a number of different sources (documents and multiple informants). In the case of more formal partnerships, examining a critical incident allows us to comment on the nature and dynamics of those partnerships under different 
conditions, and to assess the relationship, if one exists, between partnership arrangements and program performance.

Good practices in local and regional development are to some degree the result of unique historical, local and regional conditions. The relevant properties of localities are local entrepreneurship, locally embedded networks, local culture, local skills relevant to new ways of exploiting local resources, and local and regional policymakers, for example. They can be conditioned by local history and nature, or by a local knowledge base, which may be social, cultural or craft-based. In addition, a firm's interaction with its locality can vary, as innovative firms can be either isolated from or embedded into a local production system, and they can act as driving forces in wider local development processes. Good practices in local and regional development policies can also result from nationally unique conditions and policy systems, such as national innovation systems, and national policy instruments.

A good practice analysis can be carried out by examining the following phases:

\section{Phase: The weak hypothesis}

The weak hypothesis is a description of an idea that some actors started by carrying out certain actions, which were locally anchored and had certain favorable outcomes and results. This is the initial description of a good practice. It is important to determine the boundaries of a good practice in order to differentiate between the good practice and its context. A good practice description can be characterized as a 'weak theory', the initial, weakly substantiated version of the story, consisting of a cause and effects.

\section{Phase: Creating the story of good practice}

In the second phase the story is substantiated by gathering new data related to it from different perspectives and told by different actors. In order to capture the different perspectives of good practice, and to avoid preconceptions about the story, it is important to try and find a great diversity of perceptions and interpretations concerning the process generating good practice. A favorable outcome or outcomes may have many causes. Knowledge used in substantiation can be abstracted from observable data, interpretations, attributions, and generalizations. In cases where the receiving area is familiar, it is possible to substantiate the story through interaction with the actors from the area receiving the good practice, and the perspectives and interests of the receiving area can be included in the data gathering of the good practice.

The ways good practices work do not only depend on the mechanism but also the context in which they exist has to be taken into account. Information about the receiving context helps 
us to verify to what extent good practice is independent of, and on the other hand embedded in its context (Vesely 2011: 115).

The data is gathered through interviews as well as by gathering different documents and other secondary sources related to the good practice and its role in local development. First, however, the relevant actors in relation to the good practice should be identified. The interviews should deal both with the actors in the context of the good practice and with those outside of it, as it is important to include perspectives from every significant point of view. Also researchers should try and be perceptive of the interests of the receiving policy makers, as they may, for instance, have an interest in specific data on support levels or policy programs. Thus we can generate a 'thick' description, close to the 'empirical realities' of what has been going on and why, and at the same time emphasize the aspects relevant to the receiving areas. This also means clarifying how the outcome of the good practice is explained within different sectors, as well as in its specific regional and national context.

After gathering all the relevant data a story of thick description can be written. The story is meant to describe the factors leading to success, the process and structure of the good practice, and its inner and outer context, etc. It should consist of narrative accounts of outcomes and explanations regarding the dynamics of the case. In other words a clarification as to what caused a series of events or phenomena to unfold and end the way they did. The narrative is based on the plots or themes of the story, and it consist of interpretations of events and causal mechanisms of the good practice.

\section{Phase: Analysis of the story}

The thicker story of a good practice is embedded in a unique context, which can never be completely replicated anywhere else in the world. Instead, the analysis of the story may help us to identify elements of the original story, which are more or less abstract. This act of abstraction is dis embedding, which means that the 'core' of elements which appear to be relevant to others is extracted. In this phase factors and mechanisms that can explain changes at the local and national level are identified, as well as to what extent the good practice is locally embedded. The aim is to answer the question of what is the role of situational factors in the operation of a good practice? The result of this phase is a description of the abstracted elements of the thicker story of a good practice.

\section{Phase: ba as focus group meetings}

The dis-embedded elements of a good practice can be applied in practice within other contexts, creating a movement from the abstract to the concrete which is re-embedding. Reembedding is a translation that has been conducted between the historical and situational contingencies of a successful experiment and those of the context where similar ideas and 
actions are put into force. To what extent are the abstractions generated through dis-embedding useful in redirecting the attention of actors who are embedded in other contexts? The answer to this question depends on the outcome - when we confront practitioners with our findings in focus group meetings.

In focus group meetings, an atmosphere is created where two sets of operational knowledge, the abstract elements of the good practice and the knowledge of the actors in the receiving area, are considered equal, positive and 'sympathetic' towards each other (field building). In a peer group atmosphere, decisions are expected to be made based on mutual consensus, applying the principle of 'direct democracy', where externally determined authority relations between participants, and between participants and researchers, are explicitly disregarded, through certain rules of the game that are established in the meeting.

5. Phase: Rewriting the experiences

The idea is that after the focus group meeting researchers include their own insights to these dialogues and rewrite the major findings into reports that aim to be inclusive and multivoiced.

\section{Abduction: evaluation of good practices}

Abduction starts from the realization that our information is incomplete. With this information a weak hypothesis is developed through a logic which is akin to intuition or guessing.

1. We know that practice P1 works well in region A, and we have a preliminary understanding of why it works so well, in other words the causal chain which creates this desired outcome described in the good practice analysis.

2. We know that there are certain similarities between region $A$ and region $B$.

3. We observe that this practice is not applied in region B. Instead, region B has another practice, P2, with another outcome, which seems to be less optimal.

4. In this situation we may make a guess, regarding whether P1 can be transferred from region A to region B. This guess is a weak hypothesis.

Abduction means that we hypothetically take the practice P1 from region A, make a good practice analysis according to the above mentioned principles, and after that try to understand how it may be applied in region B. If the regions A and B are similar in all other aspects which are relative to $\mathrm{P} 1$, we might find that $\mathrm{B}$ can simply copy $\mathrm{P} 1$.

If region A has a hegemonic position, say, it is broadly recognized as the 'Silicone Valley' of these types of regions, there might be a strong political motivation to copy $\mathrm{P} 1$ in region $\mathrm{B}$. 
In this situation the selection mechanism of region $\mathrm{B}$ may be wide open to P1. If, in addition, $\mathrm{A}$ and $\mathrm{B}$ turn out to be similar when it comes to crucial institutional and structural preconditions in making $\mathrm{P} 1$ work, $\mathrm{B}$ is also likely to be able to apply a copy of $\mathrm{P} 1$ in practice. If so, the absorptive capacity of region $\mathrm{B}$ exists, and the full circle of the SECI process may be completed. The outcome is a copy of $\mathrm{P} 1$ in region $\mathrm{B}$.

To describe this process in more detail, first, there is another practice, $\mathrm{P} 2$, in region $\mathrm{B}$. Even though P2 may be inferior when it comes to regional development outputs, compared to P1, it might be hard to document that this is the case. Secondly, there are institutional arrangements in place in region B which are likely to be supportive of P2. For example, there might be job descriptions, job contracts and other institutional arrangements which are mobilized to defend P2. The institutional arrangements which have to be in place to support P1 might not be available in region B. Further, the institutional leaders (know-who) of region B may join up to prevent the implementation of $\mathrm{P} 1$. Still, it is worth questioning whether region $\mathrm{B}$ should copy A in the first place. All in all, there are likely to be obstacles when it comes to the selection (know-who) and absorption (know-how) of good practices.

\section{Translation of good practices}

At this point, the transfer project is likely to run into difficulties. For example, one may simply be forced to realize that there is no point in proceeding, and that perhaps another direction would be more adequate. After all, the idea of abducting P1 was a weak hypothesis that has since been rejected. Also, the question arises whether it was wrong to start comparing A and B in the first place. Maybe B should look into practices in other regions? If, however, there is evidence of the contrary, we may continue.

Several strategies are possible.

1. First, the functions of P1 and P2 can be studied, compared and analyzed closer. Why, in fact, is it assumed that P1 is better than P2? This relates to the root cause analysis discussed in chapter 4.

2. Secondly, one might start to question the kinds of actions that are actually possible in region B, given its institutional makeup and the ways its leadership works. What are the preconditions for development inside region B? At this point we should take the emergence of B into consideration.

3. Third, one may start to look at P1 itself. Given the fact that P1 is an appropriate solution to a problem in the context of region $\mathrm{A}$, and thatP2 is considered a bad solution for B, how can B, given its institutional makeup, develop not P1 but rather something better than P2? 
Justification is similar to a screening process, and it involves the process of determining if the newly created concepts are truly worthwhile for the organization and society (Nonaka and Takeuchi 1995: 86). The case study interviews, the good practice report, and the dialogue in the focus group regarding this report, may be seen as phases towards creating new conceptual knowledge of the cases. Through externalization the new conceptual knowledge may be used to discuss new combinations and re-combinations of existing systems, or archetypes.

The justified concept is converted into something tangible or concrete, namely, an archetype. An archetype can be thought of as a prototype in the case of a new product development process. In the case of a service or organizational innovation, an archetype could be thought of as a model operating mechanism. In either case, it is built by combining newly created explicit knowledge with existing explicit knowledge.

(Nonaka and Takeuchi 1995: 87)

This is the point where one can start to translate P1. We know that P1 works well under the conditions of A, but it cannot be copied by B. A translation may end up as a modified version, say, a hybrid between P1 and P2, taking the local conditions of B into consideration. This, according to Nonaka and Takeuchi, is the process of creating something new, or reconstructing an archetype. A useful tool in the reconstruction of the good practice is metaphors, described as:

'two thoughts of different things...supported by a single word, or phrase, whose meaning is a resultant of their interaction,' (Richards, 1936, p. 93 quoted by Nonaka and Takeuchi) we can continuously relate concepts that are far apart in our mind, even relate abstract concepts to concrete ones. This creative, cognitive process continues as inconsistence, or contradictions in their associations, thus often leading to the discovery of new meaning or even the formation of a new paradigm.

(Nonaka and Takeuchi opt cit page 67)

This process of translation must take into consideration what we have learnt about the ability of B to select and absorb new solutions. What, one might ask, can B actually absorb and use? In other words what is the know-how of B? Is there something which might be done in B which may point in the direction of a solution to the problem of a dysfunctional P2? By asking questions like this, we move away from just translatingP1 to engaging in a more incremental long-term process of building new institutions in B. Instead of transferring P1, we may separate P1 into different components and stages, and start by transferring the preconditions for P1. 
This is the ant hill approach, discussed in chapter 4. An ant hill strategy would start with identifying pathways into $\mathrm{B}$, through the mechanisms of selection and absorption which $\mathrm{B}$ already possesses.

If successful, these paths become reinforced.

In following these openings, or ant paths, it is possible to start to construct what might become the institutional preconditions for a new solution.

\section{Outcomes: Internalization}

After the new practice has been formed incrementally, it should be integrated and justified as part of the regional development structure. This is done through processes of internalization, when the practice becomes embodied by the actors of the receiving region. Nonaka and Konno (1998) describe this phase as exercising ba. In this phase, the new explicit knowledge, which can be a new archetype, has to be embodied in action and practice through simulations or experiments, in order to trigger learning by doing. It is an individualistic process, and a central element is the desire of the individual to renew and develop their own competencies and working procedures (see Chapter 3 , this volume).

The once abstract, codified idea now becomes a concrete, tacit praxis. In this process of internalization, the new practice is connected to the regional system and it becomes part of the new context. In order to function, the new praxis must be integrated into the institutional configurations of the receiving regions. It must find its place, develop links to other parts of the system, and make itself useful in the new context. At this point, we return back to the beginning of the cycle, the question of the on-going process of development or 'emergence' which set the entire sequence of transnational learning in motion.

This begs the question as to what type of institutional change or emergence are we actually referring to. In Chapter 1, we referred to Giddens' analysis of globalization as a Juggernaut, which rips up stable societies. On the other hand, a focus on emergence, with reference to Bob Jessop, allows for gradual institutional change. In order to explain the mechanisms of institutional change we apply a typology inspired by recent contributions from historical institutionalists (Streeck and Thelen 200; Thelen 2009). Historical institutionalists have studied the influence of internal and external factors on change and stability. Generally, the theory of historical institutionalism presents an explanation for how the relationship between the institution and actors relates to gradual change within the institution. Within this approach institutions are seen as instruments actors use to negotiate the complexity of the world. In 
Chapter 1 of this volume, Mariussen discusses this from the point of departure of the structuration theory of Giddens. Streeck, Mahoney, and Thelen provide a somewhat broader perspective with regards to these ideas.

Institutions are building blocks of social order, and they can be seen as social regimes that provide sets of rules stipulating expected behavior, and discouraging behavior deemed to be undesirable. However, those who control the institutions don't have perfect control over the rules themselves (Streeck and Thelen 2005: 16-19). Instead, institutions are distributional instruments that are charged with power implications, distributing power and other resources unequally. This asymmetric distribution of resources causes internal tensions, as actors struggle over the meaning, application and enforcement of institutional rules, resulting in either compliance or non-compliance with the rules. The creation of an institution might reflect the motivation of actors with particular resources, but also conflicts among actors with different resources and interests. The institution ends up being a reflection of the institutional preferences of the actors within it (Mahoney and Thelen 2010).

Steeck and Thelen (2005: 8) distinguish between processes of change, which may be incremental or abrupt, and the results of change, which reflect either continuity or discontinuity. Change is often endogenous and it is produced by the behavior that an institution generates itself (Streeck and Thelen 2005). Steeck and Thelen focus on transformative change as it relates to a process of an accumulation of gradual and incremental change, and argue that instead of 'big shocks' it is often a number of smaller events that lead to major historical discontinuities.

Mahoney and Thelen (2010) argue that change occurs when problems of rule interpretation and enforcement give actors within an institution an opportunity to implement these rules in new ways. Those who benefit from the existing set up may be interested in continuity, whereas those with diverging interests favor change. Efforts to maintain an already established institution are manifested as an on-going mobilization of support for the institution. Change may imply a shift in the power balance.

Institutional change (Table 5.4), according to Mahoney and Thelen, can be classified according to two broad dimensions. First, there is the ability of the defenders of the status quo to veto change. Secondly, there is the question of discretion when it comes to the interpretation of what this change actually means, and accordingly, how it should be enforced in practice.

There are four possibilities when it comes to implementing the good practice against resistance (based on Mahoney and Thelen 2010: 19). 
Following this classification, Streeck and Thelen (2005) point out that institutional change can be divided into five gradual but nevertheless transformative modes: displacement, layering, drift, conversion, and exhaustion.

Table 5.4 Typology of institutional change

\begin{tabular}{|l|l|l|}
\hline & Low level of discretion & High level of discretion \\
\hline Strong veto possibilities & Layering & Drift \\
\hline Weak veto possibilities & Displacement & Conversion \\
\hline
\end{tabular}

Displacement means the removal of existing rules and the introduction of new ones, in a situation where resistance is broken down, and implementation is explicit and transparent. In this phase new models emerge, diffuse, and call into question existing, previously taken-forgranted organizational models and practices. Some institutional arrangements may support the dominant logic of action, but these coexist with other arrangements, created at different points in time, which might embody conflicting and even contradictory logic. New institutional arrangements are often introduced by actors that can be considered losers in the existing one. The emergence of new institutional arrangements can happen through a radical shift or a slowly evolving process where new arrangements are presented, which compete with existing ones, rather than replacing them directly.

This displacement-effect might come as a result of a successful process of transnational learning, as in the case of New Public Management and World Heritage, for example.

Layering means the introduction of new rules on top of or alongside existing ones, without actually replacing the institution. In other words the existing institutions are revised or combined with new ones. Layering often happens when defenders of the status quo prevent a complete turnover of the institution but are not against the introduction of amendments and modifications. Layering involves the active combining of amendments, additions, or revisions with an existing set of institutions. The actual mechanism for change is differential growth; the introduction of new elements that set in motion certain dynamics through which, over time, the old system is crowded out. Layering may also mean new complementarities between the new institution and the old.

An example of layering is when a program for 'sustainable tourism' was introduced in relation to World Heritage Sites, complimented with networks of sociologists studying the ways in which locals had adapted to WH status. If actors decide to accept and promote this action, 
support from abroad in developing the new rules may be welcomed. A program of sustainable tourism may strengthen the local support for protection, or undermine it, as has been the case in regions where tourism has simply acted to draw the attention of Al Qaida, for example.

Drift refers to the changed impact of existing rules due to shifts in the environment. In these cases the existing institution is successfully defended, but its basis of existence is eroded. If actors choose not to respond to changes in the external context the impact of the institution within that context changes. Institutions require active maintenance, and in order to remain as they are they need to be refocused in response to changes in their political and economic environment.

Conversion is the fourth mode of change. Different from layering and drift, here institutions are not so much amended or allowed to decay, but instead they are redirected towards new goals, functions or purposes. Redirection can come about as a result of new environmental challenges, or through changes in power relations. Actors intentionally exploit the inherent ambiguities of the institution, and thus they can direct the institution towards new goals and functions. This means that new elites may come to power and organize the shift from within the institution in the direction of their preferred interests (Mahoney and Thelen 2010). One example of this is the OMC process, which may be seen as the construction of a multilevel governance system and policy convergence from within.

Exhaustion means institutional breakdown, rather than change. With exhaustion the collapse is gradual rather than abrupt. Different from institutional drift, in which institutions may retain their formal integrity, institutional exhaustion is a process in which behaviors initially allowed under the existing rules operate to undermine the very same behaviors. The integration of new rules or praxis from abroad may act as a response to these gradual processes of exhaustion, as it may provide important stimuli for institutional change in the region.

The typology of institutional changes can be applied in selecting and justifying the archetype in the receiving region. The new archetype can be integrated into the local system through the displacement of the rules of the earlier practice in a layered manner, attaching the new archetype to the existing practice, or as a result of conversion, where old rules are reinterpreted and enacted in a new way. As illustrated in the above discussion, this may be seen as a full SECI circle.

This introduces the question, what comes next? Will the new element stay, or will it be subjected to the same waves of change which brought it in the first place? In the previous discussion, we have seen how a full circle of SECI, resulting in the successful case of transnational learning, may lead to another circle. In successful OMC cases, institutional change is the result of repetition, as the first round of peer reviews leads to the next round. Indeed, this reiteration of 'soft' policy, such as peer reviews, was part of the strategy of displacement, 
which gradually turned the multilevel governance system into a more and more centralized one within the policy sector. Similarly, in the case of WH, with the introduction of 'sustainable tourism', the layering strategy may be seen as a necessary step towards preventing criticism and the unintentional destruction of the Sites the List aims to protect. In some of the agency bonfire cases, on the other hand, the second round of SECI process led to displacement (a completely new solution), exhaustion, or conversion, away from the original agency model.

More generally, these processes, with sequences of SECI, may at least in some cases be regarded as cumulative learning. As discussed in the introduction to this chapter, cumulative learning takes place within certain parameters, where the basic knowledge which was present from the start is protected. This model can be referred to as the staircase, where new solutions become stronger while old knowledge is also respected.

\section{REFERENCES}

Argyris, C. and Schön, D. (1978) Organizational Learning: a theory of action perspective. Cambridge: Cambridge University Press.

Bellini, N., Danson, M. and Halkier, H. (2012) 'Regional development agencies: a generational story', in Bellini, Danson and Halkier (eds) Regional Development Agencies: The Next Generation, 1-6, Regions and cities series, Abingdon, Oxon, USA, Canada: Routledge.

Boje, D. M. (2001) Narrative Methods for Organizational \& Communication Research, London: SAGE Publications.

Carayannis, E., Kaloudis, A. and Mariussen, Å. (eds) (2008) Diversity in the Knowledge Economy and Society: heterogeneity, innovation and entrepreneurship, Cheltenham: Edward Elgar.

Dahlström, M., Olsen S.L. and Halkier, H. (2012) 'Multi-actor and multi scalar regional development policies in the knowledge economy' in Bellini, Danson and Halkier (eds) Regional Development Agencies: The Next Generation, 7-23, Regions and cities series, Abingdon, Oxon, USA, Canada: Routledge.

Dolowitz, D. and Marsh, D. (2000) 'Learning from Abroad: The role of policy transfer in contemporary policy-making governance', An International Journal of Policy and Administration 13(1): 5-24, USA, UK: Blackwell Publishers. 
Drost, A. (1996) 'developing sustainable tourism for World Heritage Sites', Annals of Tourism Research 23(2): 479-92.

European Commission (2012) Guide on regional/national Research and Innovation Strategies for Smart Specialisation (RIS ${ }^{3}$ ). Online. Available HTTP: <http://s3platform.jrc.ec.europa.eu/s3pguide> (accessed 10 October 2012).

European Union (2004) CREST report on the application of the open method of coordination in favour of the Barcelona research investment objective, Scientific and Technical Research Committee 1.10.2004.

Grabher, G. (1993) The Embedded Firm: on the socioeconomic of industrial networks, London: Routledge.

Groenendijk, N.S. (2009). EU and OECD benchmarking and peer review compared. At the 3rd EUCE annual conference 'The EU in a comparative perspective'. European Union Center of Excellence: Dalhousie University, Halifax, Canada (April 26-28, 2009).

Harmaakorpi, V. (2006) 'Regional development platform method as a tool for regional innovation policy', European Planning Studies 14(8): 1093-112.

Kristensen, P.H. (2009) 'Conclusion: Developing comprehensive, enabling welfare states for offensive experimentalist business', in P.H. Kristensen and K. Lilja (eds) New Modes of Globalizing: Experimentalist forms of economic organization and enabling welfare institutions. Lessons from the Nordic Countries and Slovenia, 296337, Helsinki: Helsinki School of Economics, Publications B-100.

Kröger, S. (2009) 'The Open Method of Coordination: Underconceptualisation, overdetermination, depoliticisation and beyond', in S. Kröger, (ed.) What We have Learnt: Advances, pitfalls and remaining questions in OMC research, European Integration online Papers (EIoP), Special Issue 1, Vol. 13, Art. 5, Online. Availabe HTTP: <http://eiop.or.at/eiop/texte/2009-005a.htm> (accessed 20.7.2012).

Latour, B. (2005) Reassembling the Social: An introduction to actor-network theory, Oxford: Oxford University Press.

Mahoney, J. and Thelen, K. (2010) 'A theory of gradual institutional change', in J. Mahoney and K. Thelen (eds) Explaining Institutional Change: Ambiguity, agency and power, 1-37, New York: Cambridge University press.

Mariussen, Å. Karlsen, A. and Andersen O.J. (1996) Omstilling-fralösriving til nyforankring, Oslo: Norwegian University Press. 
Mariussen, Å. (2010) Regional mobilisering genom jämförelse och lärande, kommuner, turister, potatis och mjölk, Working Papers in Demography and Rural Studies 6. Online. Available HTTP: http://www.vasa.abo.fi/rurban/pub/6_2010.pdf (accessed 20 May 2012).

Massachusetts Institute for Technology (2012) Field Manual for a Learning History. Online. Available HTTP: http://ccs.mit.edu/lh/intro.html> (accessed 20 May 2012).

Mendez, C. (2011) 'the Lisbonization of EU cohesion policy: a successful case of experimentalist governance?' European Planning Studies 19(3): 519-37.

Nonaka, I. and Takeuchi, H. (1995) The Knowledge-Creating Company. How Japanese companies create the dynamics of innovation, Oxford: Oxford University Press.

Nonaka, I. and Konno, N. (1998) 'The concept of "Ba". Building a foundation for knowledge creation', California Management Review 40(3): 40-54.

Polkingthorne, D. (1988) Narrative knowing and the human science, Albany: State University of New York Press.

Sabel, C. (1992) Learning by Monitoring: the institutions of economic development, Working Paper 102, New York: Colombia University School of Law.

Sabel, C. (2006), 'A Real-Time Revolution in Routines', in C. Heckscher and P.S. Adler (ed.) The Corporation as a Collaborative Community, May 2006, 106-56.

Sabel, C. and Zeitlin, J. (2010) 'Learning from difference: the new architechture of experimentalist governance in the EU', in C. Sabel and J. Zeitlin (eds) Experimentalist Governance in the European Union: Towards a new architecture, 1-28, Oxford: Oxford University Press.

Scharpf, F.W. (1998) Governing in Europe Effective and Democratic? Oxford, New York: Oxford University Press.

Scharpf, F. W. (2002) 'The European Social Model: Coping with the Challenges of Diversity', JCMS: Journal of Common Market Studies 40(4): 645 - 70.

Stone, D. (2004) 'Transfer agents and global networks in the "transnationalization" of policy', Journal of European Public Policy 11(3): 545-66, UK: Routledge.

Streeck, W. and Thelen, K. (2005) 'Introduction: institutional change in advanced political economies', in W. Streeck and K. Thelen (eds) Beyond Continuity: institutional change in advanced political economies, 1-39, Oxford: Oxford University Press. 
Thelen, K. (2009) 'Institutional change in advanced political economies', British Journal of Industrial Relations 47(3): 471-98.

Thomas, A. (2004) Research Skills for Management Studies, London: Routledge.

UNESCO (1972) Convention Concerning the Protection of the World Cultural and Natural Heritage, Paris, 16 November.

UNESCO World Heritage Centre (2002) Operational Guidelines for the Implementation of the World Heritage Convention, United Nations educational, scientific and cultural organisation intergovernmental committee for the protection of the world cultural and natural heritage, UNESCO World Heritage Centre 7, place de Fontenoy 75352 Paris 07 SP $163 \mathrm{p}$.

Vesely, A. (2011) 'Theory and methodology of best practice research: a critical review of the current state', Central European Journal of Public Policy 5(2): 98-117.

Virkkala, S. and Niemi, K. (2006) 'Introduction', in S. Virkkala and K. Niemi (eds) Peripheral Localities and Innovation Policies: Learning from good practices between the Nordic countries, 5-19. Nordic Innovation Centre. 